В.В. Коваль

Генеральний штаб Збройних Сил України, Київ

\title{
СУКУПНІСТЬ ПОКАЗНИКІВ ДЛЯ ОЦІНЮВАННЯ ПРОГНОЗОВАНОЇ ЕФЕКТИВНОСТІ ЗАСТОСУВАННЯ СИЛ I ЗАСОБІВ МАСКУВАННЯ ДЛЯ ЗАХИСТУ ВІЙСЬКОВИХ ОБ'ЄКТІВ ВІД ТЕХНІЧНИХ ЗАСОБІВ ПОВІТРЯНОЇ РОЗВІДКИ ТА НАВЕДЕННЯ ЗБРОЇ ПРОТИВНИКА
}

Аналіз локальних війн та збройних конфліктів сучасності переконливо свідчить про зростання ролі заходів маскування для захисту військових об'єктів від технічних засобів повітряної розвідки та наведення зброї противника. У статті запропоновано сукупність показників для оцінювання прогнозованої ефективності застосування сил і засобів маскування, застосування яких дозволяє здійснити порівняльне оцінювання можливих варіантів формування їх складу та визначити ступень досягнення мети проведених заходів маскування в операџіях (бойових діях).

Ключові слова: маскування, захист, показник, ефективність, ступень досягнення мети, технічні засоби повітряної розвідки та наведення зброї.

\section{Вступ}

Постановка завдання у загальному вигляді та його зв'язок із практичними заходами. Результати аналізу локальних війн та збройних конфліктів сучасності, досвіду застосування військ (сил) в ході проведення операції Об'єднаних сил (антитерористичної операції) переконливо свідчать про зростання ролі заходів маскування для військових об'єктів від технічних засобів повітряної розвідки та наведення зброї (ТЗПРНЗ) противника [1-3]. При цьому успішне проведення заходів маскування неможливе без вибору раціонального складу сил і засобів маскування. Обгрунтований вибір раціонального складу сил і засобів маскування потребує формування відповідної сукупності показників для оцінювання прогнозованої ефективності їх застосування для захисту військових об'єктів від ТЗПРНЗ противника, що і обумовлює актуальність даної теми.

Аналіз останніх досліджень і публікацій. Загальні підходи до оцінювання прогнозованої ефективності застосування сил і засобів маскування в операціях (бойових діях) розкриваються в низці наукових робіт $[1 ; 3-4 ; 7-8]$. Проте, вказані методичні підходи не в повній мірі враховують те, що ефективність застосування сил і засобів маскування для захисту військових об'єктів від ТЗПРНЗ противника при визначеному варіанті їх складу характеризуються значною кількістю різних за фізичним змістом показників (ступень збереженого бойового потенціалу військових об'єктів, ймовірність своєчасного застосування сил і засобів маскування, прогнозована вартості проведених заходів маскування тощо). Тобто сьогодні в теорії військового будівництва збройних сил відсутній комплексний підхід до оцінюван- ня прогнозованої ефективності застосування сил і засобів маскування для визначення їх раціонального складу під час виконання завдань захисту військових об'єктів від ТЗПРНЗ противника в операції (бойових діях).

Тому метою статті $є$ формування сукупності показників для оцінювання прогнозованої ефективності застосування сил і засобів маскування, які дозволяють здійснити порівняльне оцінювання можливих варіантів формування їх складу та визначити ступень досягнення мети проведених заходів маскування в операціях (бойових діях).

\section{Виклад основного матеріалу}

Раціональний склад сил і засобів маскування для захисту військових об'єктів від ТЗПРНЗ противника має визначатися на підставі врахування воєнно-економічної доцільності проведення заходів маскування в операції (бойових діях). Сформований раціональний варіант складу сил і засобів маскування, насамперед, повинен задовольняти цілям застосування військ (сил) в операції (бойових діях) при мінімальних витратах ресурсу. Тобто раціональний склад сил і засобів маскування військових об'єктів повинен бути збалансованим і забезпечувати потрібну прогнозовану ефективність їх застосування при мінімальній вартості.

Основними етапами процесу формування ращчіонального складу сил і засобів маскування для захисту військових об'єктів від ТЗПРНЗ противника є:

формування можливих варіантів складу сил та засобів маскування військових об'єктів;

визначення сукупності показників, які характеризують властивості варіанту складу сил та засобів 
маскування військових об'єктів, що утворюють систему маскування;

оцінювання показників, які характеризують властивості варіанту складу сил та засобів маскування військових об'єктів;

визначення раціонального складу сил та засобів маскування військових об'єктів.

Під варіантом складу сил і засобів маскування для захисту військових об'єктів від ТЗПРНЗ противника розуміють організовано та структурно впорядковану сукупність взаємопов'язаних сил та засобів, застосування яких направлено на приховування від противника військових об'єктів, введення його в оману відносно наявності, розміщення, складу, стану, дій на намірів військ (сил).

Варіанти складу сил і засобів маскування для захисту військових об'єктів від ТЗПРНЗ противника формуються 3 використанням евристичних методів. Під час використання евристичних методів ураховується попередній досвід формування раціонального складу сил і засобів маскування військових об'єктів в ході заходів оперативної підготовки, воєнних конфліктів сучасності [4; 8].

Результативність функціонування та якість кожного варіанту складу сил та засобів маскування оцінюється показниками, які є числовими характеристиками і виступають кількісною мірою якості створення і функціонування системи маскування військових об'єктів.

До складу такої системи входять відповідні підсистеми: управління силами та засобами маскування; розвідки та попередження про дії технічних засобів розвідки противника; маскування військових об'єктів; матеріально-технічного забезпечення.

Якість системи маскування військових об'єктів визначається зовнішніми та внутрішніми властивостями.

Зовнішні властивості виявляються під час взаємодії системи із зовнішнім середовищем (функціонування системи) - під час захисту військових об'єктів від ТЗПРНЗ противника.

Внутрішні властивості характеризують створення і підготовку системи до функціонування.

Для оцінювання різноманітних властивостей системи маскування використовується відповідна сукупність показників прогнозованої ефективності застосування сил і засобів маскування для захисту військових об'єктів від ТЗПРНЗ противника.

Під показником прогнозованої ефективності розуміють кількісну характеристику, яку використовують для оцінювання окремої властивості або сукупності властивостей процесу маскування військових об'єктів.

Результати аналізу застосування існуючих методичних підходів, які можуть бути використані для визначення раціонального складу сил і засобів мас- кування для захисту військових об’єктів від ТЗПРНЗ противника, свідчать, що їх застосування не повною мірою забезпечує вирішення завдання щодо визначення їх збалансованого складу. Це, насамперед, обумовлено вирішенням такої задачі з обмеженнями, коли для порівняльного оцінювання можливих варіантів (альтернатив) в якості узагальненого показника (підстави для оцінювання варіанту) беруть один із основних показників прогнозованої ефективності маскування або співвідношення двох показників [4;8].

За таких умов задачу визначення раціонального складу сил та засобів маскування військових об'єктів доцільно вирішувати 3 використанням методів багатокритеріального аналізу (багатокритеріальної оптимізації). При цьому, для всебічного аналізу можливих варіантів складу сил та засобів маскування військових об'єктів доцільно застосовувати сукупність показників, до яких висуваються такі загальні вимоги $[4 ; 8]$ :

повнота оцінювання прогнозованої ефективності застосування сил і засобів маскування в операції (бойових діях);

відповідність меті та завданням застосування сил та засобів маскування в операції (бойових діях);

чіткий оперативно-тактичний або фізичний зміст показників;

чутливість показників до впливу внутрішніх та зовнішніх факторів;

простота обчислень показників;

узгодженість показників різного рівня.

Визначені у відповідності до даних вимог показники прогнозованої ефективності застосування сил i засобів маскування при визначеному варіанті їх складу повинні забезпечити можливість кількісного визначення ступеня досягнення результатів функціонування системи маскування під час захисту військових об'єктів від ТЗПРНЗ противника.

Тому у ході вибору окремих показників їх доцільно додатково перевірити на відповідність таким вимогам [4-5; 8; 10]:

представництво - можливість проведення оцінювання ефективності вирішення визначеного завдання маскування;

критичність - чутливість до змін параметрів, які досліджуються;

простота - зрозумілий фізичний зміст, зручність проведення розрахунків, графічного відображення та проведення аналізу;

можливість врахування під час оцінювання випадкових процесів.

3 урахуванням невизначеності умов та факторів проведення заходів маскування в операції (бойових діях), формування доцільної сукупності показників прогнозованої ефективності застосування сил і засобів маскування для захисту військових об'єктів від 
ТЗПРНЗ противника здійснюється 3 використанням експертного методу [5-6; 9].

В якості експертів залучаються представники органів військового управління, наукових установ та вищих військових навчальних закладів, які мають досвід в організації планування застосування військ (сил) в операції (бойових діях), виконання заходів маскування.

Сформована експертами сукупність показників ефективності функціонування системи маскування повинна забезпечувати необхідну та достатню оцінку прогнозованої ефективності застосування сил і засобів маскування для захисту військових об'єктів від ТЗПРНЗ противника при визначеному варіанті їх складу за умов, якщо [10]:

використання будь-яких додаткових показників не впливає на прогнозовану оцінку процесу маскування військових об'єктів в операції (бойових діях);

вилучення хоча б одного з обраних для оцінювання варіанту показників ефективності істотно змінює результати вирішення задачі формування раціонального варіанту складу сил та засобів маскування військових об'єктів в операції (бойових діях).

Практика попередніх досліджень свідчить, що показники ефективності функціонування системи маскування структурно можуть бути класифіковані таким чином:

показники ефективності функціонування підсистеми управління силами та засобами маскування;

показники ефективності функціонування підсистеми розвідки та попередження про дії технічних засобів розвідки противника;

показники ефективності виконання завдань маскування військових об'єктів;

показники ефективності функціонування підсистеми матеріально-технічного забезпечення.

Ефективність функціонування підсистеми управління силами та засобами маскування повинна оцінюватися на підставі використання статистичних даних, які отримуються в ході проведення заходів оперативної підготовки, практичної діяльності органів військового управління, що дає можливість враховувати рівень органів військового управління.

Для оцінювання ефективності функціонування підсистеми управління силами та засобами маскування пропонується використовувати такі показники:

ступінь своєчасного виконання завдань маскування військових об'єктів в операції (бойових діях);

ступінь відповідності рішень, які приймає орган військового управління 3 питань маскування військових об'єктів, діям противника та можливостям своїх військ (сил).

Дані показники характеризують зовнішню та внутрішню ефективність підсистеми управління силами та засобами маскування, дозволяють порів-

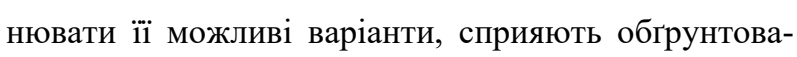
ному формуванню вимог до перспективних зразків управління силами та засобами маскування, у тому числі до автоматизованих систем.

В якості показників ефективності функиіонування підсистеми розвідки та попередження про дії ТЗПРНЗ противника доцільно використовувати:

прогнозовану імовірність виявлення засобів повітряного нападу противника засобами розвідки;

прогнозовану імовірність своєчасного доведення інформації про дії ТЗПРНЗ противника до підрозділів маскування.

Показники ефективності виконання завдань маскування військових об'єктів повинні характеризувати різноманітні способи маскування військових об'єктів, направлені на збереження бойових можливостей своїх військ (сил) та зниження бойових можливостей військ (сил) противника.

3 урахуванням особливостей виконання завдань маскування військових об'єктів від ТЗПРНЗ противника в якості таких показників можуть бути використані:

для оцінювання ефективності виконання завдань маскування під час дезінформування противника:

ступінь впровадження хибної інформації силами і засобами маскування;

ступінь впливу сил і засобів маскування на уявлення противника про зміну співвідношення сил і засобів по напрямках дій своїх військ (сил) в операції (бойових діях);

для оцінювання ефективності виконання завдань маскування під час проведення демонстраційних заходів:

ступінь впливу сил і засобів маскування на забезпечення проведення демонстративних заходів (польотів, перевезень військ, вантажів і макетів техніки залізничним і іншими видами транспорту тощо);

для оцінювання ефективності виконання завдань маскування під час виконання заходів імітації:

ступінь правдоподібності хибних об'єктів, створених під час застосування сил і засобів маскування;

відносне збільшення часу виявлення військових об'єктів технічними засобами повітряної розвідки противника.

В якості показників ефективності виконання завдань маскування під час виконання завдань приховування військових об'єктів від ТЗПРНЗ противника можуть бути використані такі показники:

імовірність готовності сил та засобів маскування військових об'єктів до виконання завдань за призначенням;

відносне зниження кількості виявлених військових об'єктів ТЗПР противника; 
відносне збільшення кількості ТЗПР для виявлення військових об'єктів;

ступінь збереження бойового потенціалу своїх військ (сил);

математичне сподівання стійкості військових об'єктів в операції (бойових діях).

Для оцінювання ефективності функціонування підсистеми матеріально-технічного забезпечення доцільно використати показники, що характеризують:

витрати на формування складу сил та засобів маскування військових об'єктів;

витрати на виконання завдань маскування військових об'єктів в операції (бойових діях);

втрати сил та засобів маскування в операції (бойових діях).

Оцінювання показників ефективності, які характеризують властивості варіанту складу сил та засобів маскування військових об'єктів, може проводитися 3 використанням експертних методів, на підставі існуючих методичних підходів [1-12], удосконалених та нових моделей та методик.

3 урахуванням значної кількості різних за фізичним змістом показників, узагальнена оцінка прогнозованої ефективності застосування сил і засобів маскування для захисту військових об'єктів від ТЗПРНЗ противника може бути отримана за допомогою таксономічних методів [4; 11].

Основним поняттям, що використовується у таксономічних методах, $€$ так звана таксономічна відстань - відстань між точками багатомірного простору, яка обчислюється за правилами аналітичної геометрії [11]. Розмірність такого простору визначається кількістю показників ефективності функціонування системи маскування. При цьому кожному можливому варіанту складу сил та засобів маскування відповідає визначена точка у багатомірному простоpi. За допомогою таксономічної відстані визначається розташування певної точки щодо інших та її місце в усій сукупності точок. Це дозволяє впорядковувати як показники ефективності, так і можливі варі-

анти складу сил та засобів маскування, що порівнюються.

Сутність методу таксономії під час порівняння альтернатив полягає в тому, що всі показники поділяються на стимулятори і дестимулятори з урахуванням їх впливу на кінцевий результат. Далі будується еталонний варіант складу сил та засобів маскування (точка у багатомірному просторі) 3 максимальними значеннями показників - стимуляторів і мінімальними значеннями показників - дестимуляторів.

В подальшому визначаються таксономічні відстані між точкою, яка відповідає еталонному варіанту складу сил та засобів маскування, і точками, які відповідають решті можливих варіантів. Ці відстані нормуються, і тим самим забезпечується ранжирування можливих варіантів складу сил та засобів маскування.

Оцінювання ступеня відповідності рівня прогнозованої ефективності застосування сил і засобів маскування рівню, який забезпечує гарантований захист військових об'єктів від ТЗПРНЗ противника за визначеним варіантом складу сил та засобів маскування, здійснюється 3 використанням прийнятого на основі концепції придатності критерію припустимого середнього результату [13].

Для визначення значень такого критерію доцільно використати вербально-числову (змішану) спеціальну шкалу Харрінгтона, що включає у себе як елементи вербальної шкали - змістовний опис градацій, так і числової шкали - числові значення, що відповідають кожній з градацій. Дана шкала дозволяє виміряти ступінь вираженості показника, який має суб'єктивний характер та відображає специфіку прийняття управлінського рішення [14].

Перелік градацій у такій шкалі (табл.) дозволяє провести оцінювання значення рівня прогнозованої ефективності застосування сил і засобів маскування для захисту військових об'єктів від ТЗПРНЗ противника та визначити рівень за якого забезпечується гарантований захист військового об’єкту.

Таблиця 1

Шкала для оцінювання рівня прогнозованої ефективності застосування сил і засобів маскування для захисту військових об'єктів від ТЗПРНЗ противника

\begin{tabular}{|c|l|}
\hline $\begin{array}{c}\text { Значення показника рівня прогнозованої } \\
\text { ефективності застосування сил і засобів } \\
\text { маскування для захисту військових об'єктів } \\
\text { від ТЗПРНЗ противника, } E\end{array}$ & $\begin{array}{c}\text { Характеристика рівня прогнозованої ефективності } \\
\text { застосування сил і засобів маскування }\end{array}$ \\
\hline 1,0 & Повністю відповідає \\
\hline 0,92 & Відповідає \\
\hline 0,84 & Малий ризик невідповідності \\
\hline 0,77 & Надійна \\
\hline 0,69 & С певний ризик невідповідності \\
\hline 0,62 & Визнається можливість невідповідності \\
\hline 0,54 & Має несуттєві невідповідності \\
\hline 0,46 & Частково не відповідає \\
\hline
\end{tabular}


Закінчення табл. 1

\begin{tabular}{|c|c|}
\hline $\begin{array}{c}\text { Значення показника рівня прогнозованої } \\
\text { ефективності застосування сил і засобів } \\
\text { маскування для захисту військових об'єктів } \\
\text { від ТЗПРНЗ противника, } E\end{array}$ & $\begin{array}{c}\text { Характеристика рівня прогнозованої ефективності } \\
\text { застосування сил і засобів маскування }\end{array}$ \\
\hline 0,39 & Частково відповідає \\
\hline 0,3 & Має суттві невідповідності \\
\hline 0,23 & Ненадійна \\
\hline 0,16 & Великий ризик невідповідності \\
\hline 0,08 & Не відповідає \\
\hline 0,0 & Повністю не відповідає \\
\hline
\end{tabular}

Джерело: розроблено автором.

Результати аналізу даних табл. 1 дозволяють визначити нижню межу показника рівня прогнозованої ефективності застосування сил і засобів маскування для захисту військових об’єктів від ТЗПРНЗ противника, тобто те критеріальне значення, за якого склад сил і засобів маскування забезпечує гарантоване виконання завдань за призначенням $E \geq 0,7$.

\section{Висновки}

Таким чином, запропонована сукупність показників дозволяє оцінити рівень прогнозованої ефек- тивності застосування сил і засобів маскування для захисту військових об'єктів від ТЗПРНЗ противника та здійснювати обгрунтування раціонального складу сил та засобів маскування військових об'єктів. Подальшим напрямом досліджень за розкритою науковою проблематикою є розробка відповідного методу обгрунтування базового складу сил та засобів маскування військових об'єктів.

\section{Список літератури}

1. Застосування аерозольних утворень для захисту військових об’єктів від ударів літаків тактичної авіації / М.М. Петрушенко, О.М. Загорка, Г.В. Пєвцов, В.В. Коваль, Г.А. Кучук; за ред. М.М. Петрушенко. - Винниця - Харків: Командування Повітряних Сил Збройних Сил України; Харківський університет Повітряних Сил ім. І. Кожедуба, 2012. - 128 с.

2. Методичні рекомендації щодо маскування та імітації військових об'єктів Повітряних Сил Збройних Сил України / О.В. Возний, В.В. Коваль та ін.; за заг. ред. С.С. Дроздова. - Вінниця: Командування ПС ЗС України, 2016. - 64 с.

3. Аерозольна протидія технічним засобам розвідки високоточної зброї противника в бою та операціях / Л.Ф. Кузьменко, О.В. Джежулей, О.С. Ковальов та ін.; за ред. Р.М. Факадея. - К.: НАОУ, 2003. - 136 с.

4. Елементи дослідження складених систем військового призначення / О.М. Загорка, С.П. Мосов, А.І. Сбітнєв та ін. - К.: НАОУ, 2005. - 100 c.

5. Чуев Ю.В. Исследование операций в военном деле / Ю.В. Чуев. - М.: Воениздат, 1970. - 256 с.

6. Стратегічне управління військово-технічним співробітництвом в інтересах забезпечення воєнної безпеки України: монографія / В.М. Бегма, О.М. Загорка, В.О. Косевцов, В.М. Шемаєв; за заг. ред. І.С. Руснака. - К.: ІПНБ, НАОУ, 2005. $-228 \mathrm{c}$.

7. Методика оцінки ефективності воєнної розвідки в операції і бою. - К.: АЗСУ, 1998. - 126 с.

8. Методологічні засади обгрунтування раціональних форм та способів застосування угруповань військ (сил): Воєннотеоретична праця / В.Г. Радецький, І.С. Руснак, О.М. Загорка та ін.; за заг. ред. С.О. Кириченка. - К.: НАОУ, 2007. - 288 с.

9. Бешелев С.Д. Экспертные оценки / С.Д. Бешелев, Ф.Г. Гурвич. - М.: Наука, 1973. - 160 с.

10. Сложные технические и эргатические системы: методы исследования: монография / А.Н. Воронин, Ю.К. Зиатдинов, А.В. Харченко, В.В. Осташевский. - Харьков: Факт, 1997. - 240 с.

11. Плюта В. Сравнительный многомерный анализ в эконгмических исследованиях: Методы таксономии и факторного анализа / В. Плюта; перевод с польск. В.В. Иванова. - М.: Статистика, 1980. - 151 с.

12. Коваль В.В. До питання вибору критеріїв для оцінювання ефективності застосування засобів маскування та імітації об'єктів Повітряних Сил / В.В. Коваль, О.В. Возний, О.А. Каблуков // Наука і техніка Повітряних Сил Збройних Сил України. - 2010. - № 2(4). - С. 7-9.

13. Харрингтон Д. Управление качеством в американских корпорациях / Д. Харрингтон. - М.: Экономика, 1990. - 272 с.

14. Универсальная вербально-числовая шкала Харрингтона Електронний ресурс. - Режим доступу: https://helpiks/org/3-20657.html (дата звернення: 15.07.2020).

\section{Відомості про автора:}

\section{Коваль Володимир Валерійович}

кандидат військових наук старший науковий співробітник начальник Воєнно-наукового управління

Генерального штабу ЗС України,

Київ, Україна

https://orcid.org/0000-0002-6209-6779

\section{Information about the author:}

Volodymyr Koval

Candidate of Military Sciences Senior Research

Head of Military Science Division

of General Staff of the Armed Forces of Ukraine,

Kyiv, Ukraine

https://orcid.org/0000-0002-6209-6779 


\title{
СОВОКУПНОСТЬ ПОКАЗАТЕЛЕЙ ОЦЕНКИ ПРОГНОЗИРУЕМОЙ ЭФЕКТИВНОСТИ ПРИМЕНЕНИЯ СИЛ И СРЕДСТВ МАСКИРОВКИ ДЛЯ ЗАЩИТЫ ВОЕННЫХ ОБЪЕКТОВ ОТ ТЕХНИЧЕСКИХ СРЕДСТВ ВОЗДУШНОЙ РАЗВЕДКИ И НАВЕДЕНИЯ ОРУЖИЯ ПРОТИВНИКА
}

\author{
В.В. Коваль
}

Анализ локальных войн и вооруженных конфликтов современности убедительно свидетельствует о возрастании роли маскировки для защиты военных объектов от технических средств воздушной разведки и наведения оружия противника. В статье предложена совокупность показателей оиенки прогнозируемой эффективности применения сил и средств маскировки, использование которых позволяет проводить сравнительную оценку возможных вариантов формирования их состава и оченивать степень достижения целей проведения мероприятий маскировки в операциях (боевыр действиях).

Ключевые слова: маскировка, защита, показатель, эффективность, степень достижения иели, технические средства воздушной разведки и наведения оружия.

\section{SET OF INDICATORS TO ESTIMATE FORECASTED EFFECTIVENESS \\ OF THE USE OF FORCES AND CAMOUFLAGE MEANS FOR PROTECTING MILITARY FACILITIES FROM TECHNICAL EQUIPMENT OF AIR RECONNAISSANCE AND ENEMY WEAPON GUIDANCE}

\section{Koval}

Analysis of local wars and armed conflicts of our time indicates the growing role of camouflage measures to protect military facilities from technical equipment of air reconnaissance and enemy weapon guidance.

The article presents a set of indicators to estimate the forecasted effectiveness of the use of forces and means of camouflage. The use of these indicators allows to:

- conduct comparative assessment of possible options for the formation of their structure;

- determine the degree of achievement of the goal of the ongoing camouflage measures in operations (combat operations).

It is shown that the performance indicators of the camouflage system functioning can be structurally classified as:

- performance indicators of the functioning of the control subsystem of forces and means of camouflage;

- performance indicators of the functioning of the reconnaissance and warning subsystem about the actions of enemy reconnaissance technical equipment;

- performance indicators of the tasks of camouflaging military objects;

- performance indicators of the logistics subsystem.

A generalized assessment of the forecasted effectiveness of the use of forces and means of camouflage to protect military facilities from technical equipment of air reconnaissance and enemy weapon guidance can be obtained using taxonomic methods.

These methods involve assessing compliance with certain levels. As the first, it is proposed to use the level of the forecasted effectiveness of the use of forces and means of camouflage. As the second, there is a level that ensures guaranteed protection of military equipment from technical means of air reconnaissance and enemy weapon guidance according to certain variant of the structure of forces and means of camouflage. The conformity assessment of these levels can be carried out using the criterion of an acceptable average result. It is advisable to determine the values of the criterion using the verbal-numerical (mixed) Harrington scale. This scale allows to measure the severity of the indicator. This indicator is subjective and reflects the specifics of making management decisions. The analysis of the obtained results allows to determine the lower limit of the indicator of the level of the forecasted effectiveness of the use of forces and means of camouflage to protect military facilities from technical equipment of air reconnaissance and enemy weapon guidance.

Keywords: camouflage, protection, indicator, effectiveness, degree of goal achievement, technical equipment of air reconnaissance and weapon guidance. 